\title{
Comparison of multivariate patterns: different taxonomic levels in macrofaunal analysis versus sediment profiling imagery (SPI)
}

\author{
Heye Rumohr ${ }^{1, *}$, Ioannis Karakassis ${ }^{2}$ \\ ${ }^{1}$ Institut für Meereskunde, Düsternbrooker Weg 20, 24105 Kiel, Germany \\ ${ }^{2}$ Institute of Marine Biology of Crete, PO Box 2214, 71003 Heraklion, Crete, Greece
}

\begin{abstract}
The multivariate patterns resulting from analyses of macrobenthic abundance data at different taxonomic levels are compared to the pattern derived from various measurements obtained through sediment profiling imagery (SPI). A time-series data set from 1 station in Kiel Bay (Western Baltic) at $22 \mathrm{~m}$ depth including macrobenthic and SPI replicates covering 8 yr (1989 to 1996) was analyzed by means of multidimensional scaling (MDS) ordination. The macrobenthos data showed similar patterns, and there was little information loss, with decreasing taxonomic resolution from species to phylum level. The multivariate pattern in the SPI data was not significantly correlated to any of the macrofaunal patterns. However, macrofaunal and SPI patterns seemed to be complementary since they emphasized different aspects of the long-term succession in the Southern Baltic Sea. While macrofaunal patterns were sensitive to anoxia events, changes of SPI-recorded seabed characteristics were primarily related to physical disturbances possibly due to variations in fishing intensity.
\end{abstract}

KEY WORDS: Macrobenthos monitoring · Sediment profiling imagery (SPI) Taxonomic resolution Western Baltic $\cdot$ Multivariate analysis

\section{INTRODUCTION}

Multivariate analysis of macrofauna species-abundance data has become a standard method for the assessment of the benthic conditions and the environmental impacts of a wide range of human activities. Analysis of data at levels higher than species (e.g. family) has been proposed as a substitute for the standard analysis of species-abundance data (Warwick 1988a,b) particularly when strong pollution gradients are involved. Some papers have addressed the efficiency of using different taxonomic levels (Warwick 1988a,b, Ferraro \& Cole 1990, Somerfield \& Clarke 1995, Olsgard et al. 1997, 1998), concluding that in macrofauna studies surprisingly little information is lost even in cases where specimens are identified to the level of phylum. However, there is still a limited number of studies in which the use of abundance of higher-level

•E-mail: hrumohr@ifm.uni-kiel.de taxa has been examined as an alternative to specieslevel identification (Olsgard et al. 1998).

Sediment profiling imagery (SPI) systems, initially developed for the investigation of animal-sediment relationships (Rhoads \& Young 1970, 1971), have also been employed for investigating environmental change along pollution or disturbance gradients (Rhoads \& Germano 1982, 1986, O'Connor et al. 1989, Rumohr \& Schoman 1992, Rosenberg \& Diaz 1993, Rumohr 1993, Nilsson \& Rosenberg 1997).

Given that both methods are used for monitoring disturbance in benthic environments, it would be reasonable to test whether the information they produce is similar or not. In particular there is a lack of adequate information on how these 2 approaches behave with respect to time-series data.

The aim of the present study was to compare the performance of the SPI method to that of the standard species-abundance analysis of macrobenthic organisms in studying long-term changes in benthic systems as well as a comparison of the analyses of abundance data at 
various taxonomic levels. One time-series data set consisting of 15 sampling cruises to a station in Kiel Bay including macrofauna and SPI data was used. A methodological protocol is proposed for the quantification of SPI data so that they can be examined with standard multivariate techniques.

\section{MATERIALS AND METHODS}

Sampling site. The macrofaunal data presented came from a long-term monitoring program at the Süderfahrt (N2) station in the centre of Kiel Bay (Western Baltic). The station is situated at $22 \mathrm{~m}$ of depth with sandy/mud sediment. The location of the sampling station and the main biotic and abiotic features have been described by Arntz (1981), Andersin et al. (1990) and Weigelt (1991). In the present paper unpublished monitoring data covering a period of 8 yr (Table 1), during which both macrofaunal and SPI data were available, are presented. Cruises 3, 6 and 7 were not included in the data set due to absence of SPI data.

Analysis of macrofauna. Macrofaunal samples were collected by means of a $0.1 \mathrm{~m}^{2}$ van Veen grab, they were sieved on board through a $1 \mathrm{~mm}$ sieve, fixed in buffered formalin and were identified to the level of species. The methods followed in general the ICES and HELCOM recommendations on sampling of the benthos, and treatment of samples was also based on the ICES recommendations (Rumohr 1990). The data obtained were aggregated to the levels of genus, family, order, class and phylum in order to perform the analysis under different taxonomic resolution scenarios.

Table 1. Macrofaunal and sediment profiling imagery (SPI) data available in the years 1989 to 1996 for the Süderfahrt (N2) Station in Kiel Bay (western Baltic)

\begin{tabular}{|lccccc|}
\hline $\begin{array}{l}\text { Cruise } \\
\text { number }\end{array}$ & Date & $\begin{array}{c}\text { Macrofauna } \\
\text { replicates }\end{array}$ & $\begin{array}{c}\text { Specimens } \\
\text { identified }\end{array}$ & Species & $\begin{array}{c}\text { Number of SPI } \\
\text { photographs }\end{array}$ \\
\hline 1 & 18 Jan 1989 & 2 & 503 & 14 & 6 \\
2 & 14 Mar 1989 & 3 & 670 & 15 & 2 \\
4 & 13 Nov 1990 & 3 & 185 & 22 & 11 \\
5 & 18 Mar 1991 & 3 & 111 & 21 & 6 \\
8 & 06 Jun 1991 & 3 & 653 & 19 & 11 \\
9 & 13 May 1992 & 3 & 878 & 21 & 9 \\
10 & 11 Jan 1993 & 3 & 470 & 23 & 8 \\
11 & 07 Sep 1993 & 3 & 962 & 26 & 6 \\
12 & 01 Dec 1993 & 3 & 965 & 26 & 5 \\
13 & 04 Feb 1994 & 3 & 1380 & 27 & 4 \\
14 & 31 Mar 1994 & 3 & 1603 & 27 & 5 \\
15 & 18 May 1994 & 3 & 1395 & 25 & 3 \\
16 & 04 Oct 1994 & 3 & 1402 & 29 & 4 \\
17 & 14 Jun 1995 & 3 & 1133 & 22 & 18 \\
18 & 27 Nov 1996 & 3 & 127 & 16 & \\
\hline
\end{tabular}

Table 2. SPI attributes used for multivariate analysis

\begin{tabular}{|lcc|}
\hline Attribute & Units & Abbreviation \\
\hline Average penetration depth & $\mathrm{cm}$ & $\mathrm{PD}$ \\
Boundary roughness & $\mathrm{cm}$ & $\mathrm{BR}$ \\
Oxidised sediment depth & $\mathrm{cm}$ & OL \\
Surface sediment & $\mathrm{mm}$ & $\mathrm{SL}$ \\
Traces of bioturbation & \pm & $\mathrm{BT}$ \\
Epifauna & \pm & EP \\
Mud clasts & \pm & $\mathrm{CL}$ \\
Voids & \pm & VO \\
Tubes & \pm & TB \\
\hline
\end{tabular}

SPI data. The SPI data were collected using a modified BENTHOS REMOTSTM (Remote Ecological Monitoring of the Seafloor) camera, described by Rumohr (1995). A number of seabed attributes were selected in order to comprehensively describe major ecological attributes of the benthic environment (Table 2). These included continuous variables (penetration depth, boundary roughness, depth of oxidized layer, depth of recently deposited surface layer) and binary data (presence of bioturbation, epifauna, mud clasts, gas voids and tubes). The data of the former category entered the SPI matrix as average values of replicate photographs, the latter as frequencies in the set of replicate photographs. The number of replicate photographs per sampling event is given in Table 1. Typical examples for these attributes are given in Fig. 1. The analysis was repeated using only 2 easily detectable SPI attributes, i.e. bioturbation frequency (BT) and penetration depth (PD), and particularly avoiding attributes directly related to physical disturbance (such as mud clasts [CL]) in order to compare the pattern resulting from this minimized data set to those obtained through the analysis of the entire SPI data set and the macrofaunal analysis.

Multivariate analysis. Abundance data of all macrobenthic replicates taken at Stn N2 in each sampling cruise were averaged and analyzed by means of multidimensional scaling (MDS) ordination (Field et al. 1982). Similarities were calculated by means of the Bray-Curtis similarity index (Bray \& Curtis 1957). Prior to the analysis a double square root transformation was applied to the abundance values in order to downweight the importance of abundant species in the analysis and avoid skewness in the data set. This type of analysis is in accordance with the suggestions of 

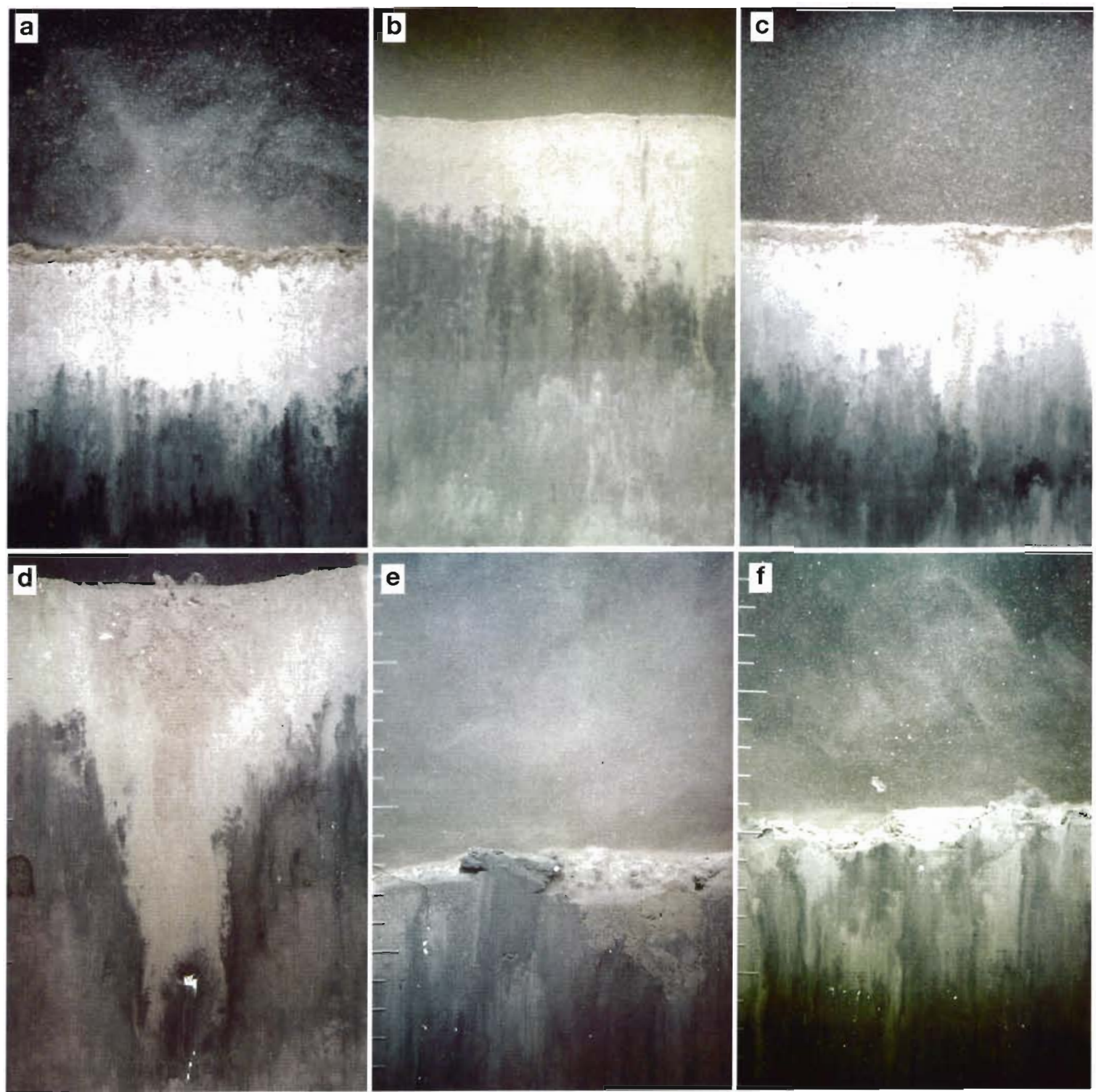

Fig. 1. Sediment profile photographs (SPI) taken at the Süderfahrt station (N2, Kiel Bay, Western Baltic) illustrating the main features used in the analysis: (a) Undisturbed sediment layers with recently deposited detritus layer (SL) on top; (b) 'apparent' redox-cline at 3 to $5 \mathrm{~cm}$ depth (OL); (c) bioturbation mark of polychaete with down-transport of surface material (BT); (d) deep

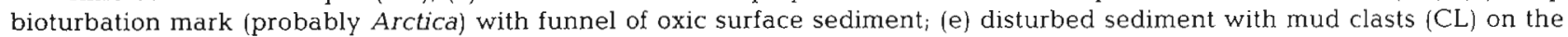

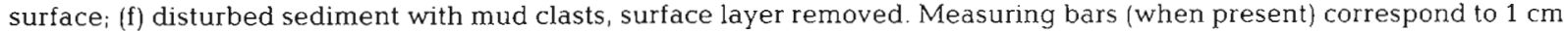

Clarke \& Warwick (1994) that intermediate transformations (such as square root or double square root) are likely to give the best balance between the 'narrow' and 'wide' views of community structure, i.e. influenced only by the dominant taxa or giving too much weight to rare taxa. Olsgard et al. $[1997,1998)$ found that data transformation plays an important role when analysing macrofaunal data under different levels of taxonomic resolution and showed that analysis at the family level and the use of square root transformation 
gave the highest correlation with environmental data. However, in the present paper the criterion for assessing the performance of different types of analysis was similarity to the pattern obtained through the analysis at the species level. Therefore, we chose to follow in detail the strategy proposed by Field et al. (1982). SPI data were transformed into 'standard normal deviates' (Sokal \& Rohlf 1978) so that each variable had zero mean and unit variance, to avoid the effect of differences in range of the variables (measured with different units), and also analyzed by means of MDS, calculating similarities by means of Euclidean distance. Analysis of correlation between similarity matrices and a 'second-stage' ordination were performed according to the approach described in Somerfield \& Clarke (1995). To make the 2 types of data sets (macrofaunal and SPI) compatible, similarity was transformed into dissimilarity in all the association matrices derived from multivariate analysis of macrofaunal data. MDS and the non parametric Spearman rank correlation coefficient were chosen since these methods need no assumptions on linearity within the data.

\section{RESULTS}

The multivariate analysis of macrofaunal data at different taxonomic levels (Fig. 2) resulted in very similar patterns for all 6 levels of taxonomic resolution. The points corresponding to the first sampling cruise covered in this analysis, which was carried out after an episode of bottom anoxia in September 1988 (Rumohr unpubl. data) are positioned at the extreme right of the 2-dimensional plots, indicating low macrofaunal similarity with samples taken in subsequent years. Following the anoxia episode the community composition changed (Cruises 2 to 10), while it remained relatively constant from September 1993 to October 1994 (Cruises 11 to 16) and deviated again after June 1995 (Cruises 17 and 18). Comparison of similarity matrices (Table 3) obtained through analysis at decreasing taxonomic resolution showed that the values of the rank correlation coefficient gradually reduced with resolution, but were not lower than $0.79(p<0.001)$.

The multivariate analysis of SPI data (Fig. 3) also resulted in a consistent pattern of community succession. The data points corresponding to the first 7 sampling periods (Cruises 1 to 10) seemed to cluster together, the samples taken during Cruises 11 to 16 followed and the final 2 points (June 1995 and November 1996) deviated towards the end of the 2-dimensional plot. The 2-dimensional plot of BT and PD also indicated a separation of the samples taken during the last 2 sampling cruises from those taken during all other cruises.

Comparison of SPI similarity matrices to those obtained through macrofaunal analysis (Table 3 ) showed very low rank correlation coefficients, indicating that
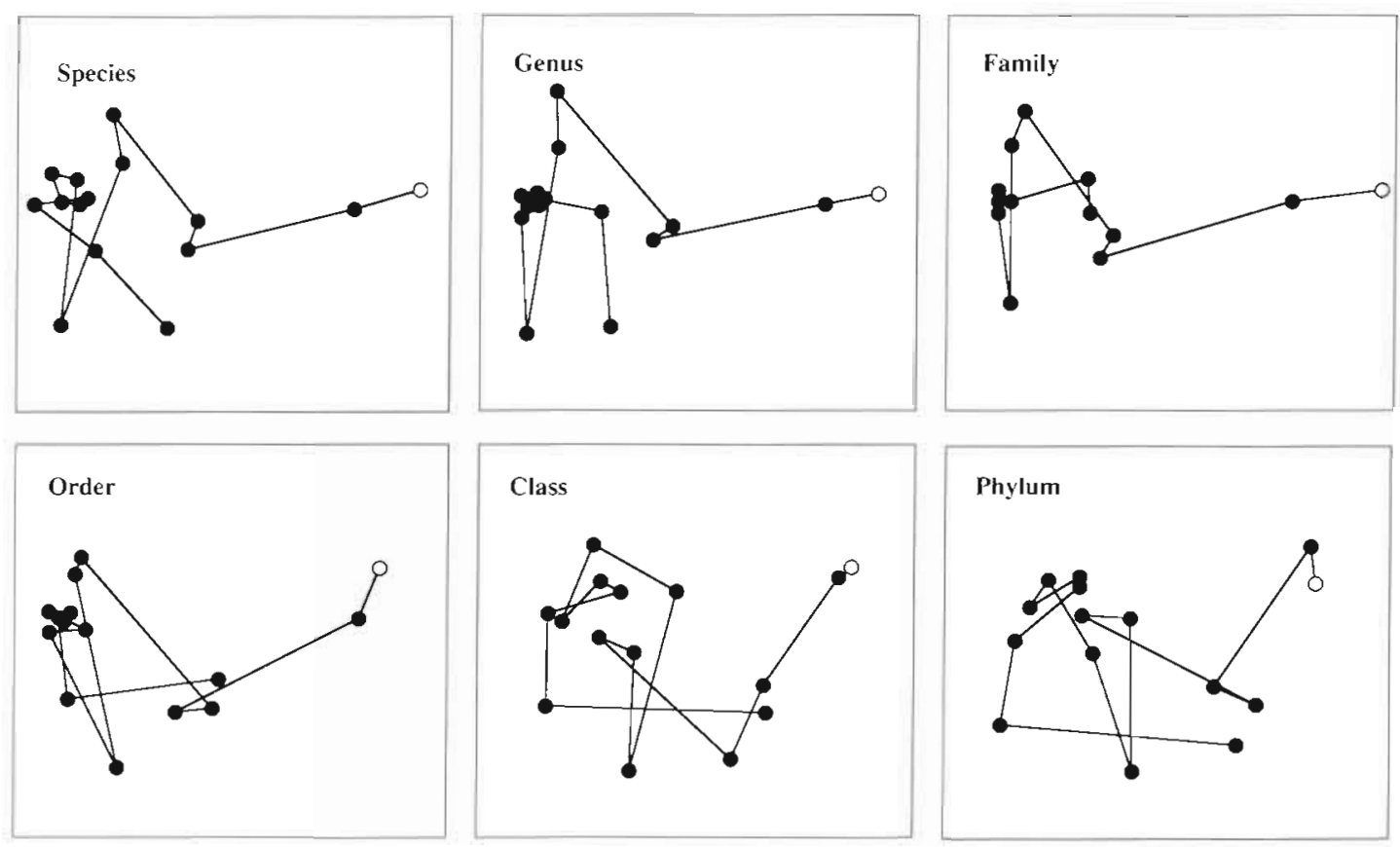

Fig. 2. MDS ordination plots of the macrobenthos abundance data. Data points from consecutive sampling periods are linked with a line; (0) first sampling cruise (18 January 1989). Stress values: species, 0.11; genera, 0.09; families, 0.09 ; orders, 0.11 ; classes, 0.13 ; and phyla, 0.13 
Table 3. Pairwise Spearman rank correlations between similarity matrices, derived from macrofaunal abundance data grouped under various hierarchical. levels and SPI data. ISPI: all variables measured included; SPI2: only penetration depth and bioturbation included)

\begin{tabular}{|c|c|c|c|c|c|c|c|c|}
\hline & $5^{2}$ & is & ह & $0^{2}$ & $0^{\infty}$ & $\hat{2}^{5}$ & $\hat{8}$ & $\hat{s}^{2 v}$ \\
\hline Species & 1.00 & & & & & & & \\
\hline Genus & 0.98 & 1.00 & & & & & & \\
\hline Family & 0.96 & 0.98 & 1.00 & & & & & \\
\hline Order & 0.91 & 0.92 & 0.94 & 1.00 & & & & \\
\hline Class & 0.80 & 0.77 & 0.79 & 0.85 & 1.00 & & & \\
\hline Phylum & 0.79 & 0.77 & 0.78 & 0.82 & 0.92 & 1.00 & & \\
\hline SPI & 0.09 & 0.03 & 0.07 & 0.03 & 0.12 & 0.13 & 1.00 & \\
\hline SPI2 & 0.31 & 0.25 & 0.26 & 0.20 & 0.23 & 0.31 & 0.53 & 1.00 \\
\hline
\end{tabular}

the patterns resulting from these 2 sources of information are quite dissimilar. This dissimilarity is graphically presented in the 'second-stage' MDS ordination plot shown in Fig. 4, which was based on the intermatrix rank correlations in Table 3, after the method described by Somerfield \& Clarke (1995). In this diagram the distance between points (corresponding to analysis under different taxonomic levels or sets of SPI attributes) reflects the degree to which the similarity matrices are correlated. From Fig 4 it is obvious that the actual choice of variables to be included in the analysis of SPI could affect the result more than the choice of a particular level of taxonomic resolution. However, the 2 configurations of SPI data clustered together in the right end of the 'second-stage' MDS ordination plot, both being quite dissimilar to the patterns obtained through macrobenthic analysis.

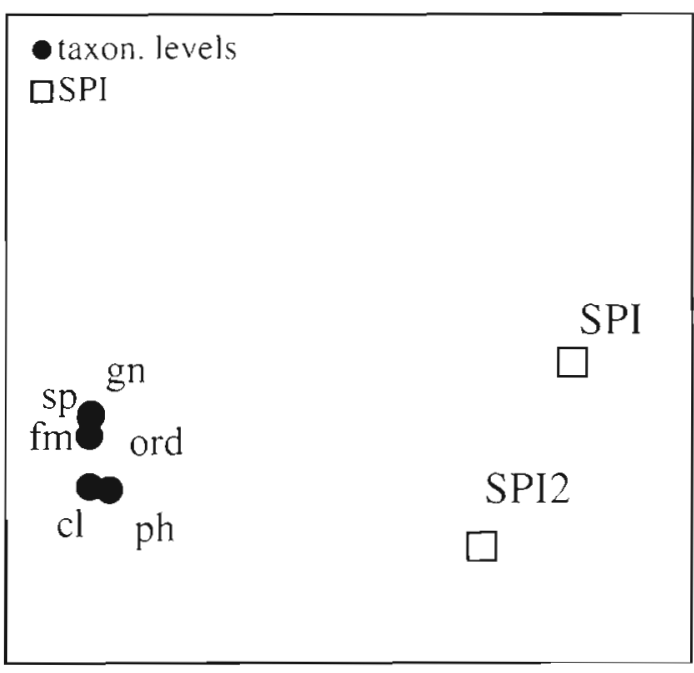

Fig. 4. 'Second-stage' ordination by MDS, of intermatrix rank correlations among macrofaunal abundance and SPI data (Table 3$)_{;}$stress $=0.01$. sp: species; gn: genus; fm: family; ord: order; ph: phylum

\section{DISCUSSION}

The results of this study confirm that the information loss when analysing macrobenthic data with decreasing taxonomic resolution, particularly up to the level of order, is very limited, as has already been reported in previous studies (Warwick 1988a,b, Somerfield \& Clarke 1995. Olsgard et al. 1998). This hypothesis has been repeatedly tested in spatial pollution gradients but only once for time-series data, from the station 'Pierre Noire' in the Bay of Morlaix, which suffered the
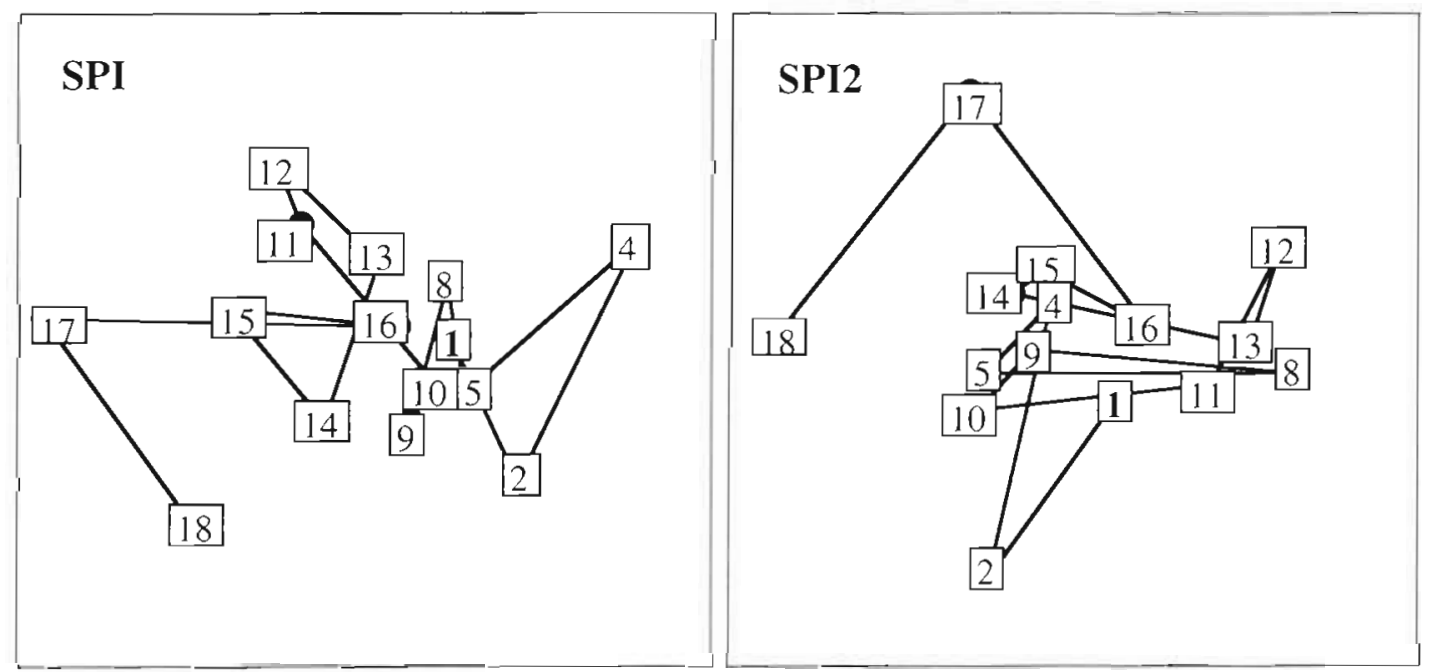

Fig. 3. MDS ordination plots for all the SPI data (stress $=0.16$ ) and SPI2 (stress $=0.00$ ), where only PD and BT were included. Data points from consecutive sampling periods are linked with a line; ${ }_{i}$ cruise numbers are given (see Table 1) 
Amoco-Cadiz oil spill (Warwick 1988a). Macrobenthic succession along organic enrichment gradients has been described by Pearson \& Rosenberg (1978). It seems that the general pattern of succession from azoic zones, through communities dominated by opportunistic species and subsequently to transitional and normal zones, is applicable to several other sources of physical disturbance (i.e. trawling, dredging and dumping) as well (Rhoads \& Boyer 1982, Rumohr 1996), whereas Olsgard (1993) has suggested that disturbance due to toxic compounds (e.g. toxic algal blooms or heavy metals) could induce a different type of response. Rumohr et al. (1996) tested the applicability of a succession model sensitive to both pollution and disturbance gradients that was developed for the Baltic and is partly based on combined image and biological information. They found that its direct applicability is restricted to the Belt Sea and southwestern Baltic only. In the more extreme conditions of the Northern Baltic the role of opportunists is taken over by ecological equivalents like chironomids (Rumohr et al. 1996). However, when strong gradients are involved, the analysis of macrofauna at higher taxonomic levels could be expected to be a useful approach (Warwick 1988a). From both Fig. 2 and Fig. 3 it seems that the interannual changes are more conspicuous than the intra-annual ones (since part of the samples did not cluster with samples taken during the same season in previous or subsequent years, but they largely deviated towards the end of the plot), which is an indication of the importance of the extreme events as factors determining the ecological characteristics in this area. Strong inter-annual variability (occasionally exceeding the intra-annual) has been reported for some of the species in this area (Arntz \& Rumohr 1986). However, this lack of seasonality could also be partly due to the fragmentation of the data set used for this particular analysis since only the sampling cruises comprising both SPI and macrobenthos were considered. Results from the present paper support the hypothesis that there is little loss of information with decreasing taxonomic resolution even in the case of relatively weak temporal gradients of disturbance. From this point of view it could be argued that reducing taxonomic resolution, for monitoring purposes, to the level of order or family is a rather cost effective method. However, the information obtained through the analysis of macrofauna is not only that contained in an ordination plot. Therefore, the analysis at the species level should not be regarded as unnecessary since other methods relating species abundance to biomass (such as the abundance-biomass comparison curves proposed by Warwick 1986) could provide a biologically more comprehensive insight into the structural changes induced by disturbance. Also, a good deal of biologically rele- vant information could be lost, such as living strategies, feeding types, etc., when collecting data on higher taxonomic levels. This is especially true for areas with a reduced species spectrum (i.e. Central and Northern Baltic).

Furthermore the use of this type of analysis for the so-called 'rapid assessment of biodiversity' (Olsgard et al. 1998) needs to be further investigated since there is no sound scientific paradigm that biodiversity is evenly distributed among all levels of biological organization. An extreme example of potentially misleading results through this type of analysis would be the conclusion that the marine environment has more species than the terrestrial one due to the larger number of marine phyla (Grassle et al. 1991), whereas it is well known that insects alone and particularly Coleoptera comprise the vast majority of animal species on the planet.

Our results indicate that the information resulting from SPI may not be used as a surrogate for macrofaunal analysis in this type of gradient although a better match of patterns could be expected in strong spatial gradients. The 2 methods should therefore be considered as complementary rather than alternative since they seem to be sensitive to different sources of variation within the benthic environment: the analysis of macrofaunal data was particularly sensitive to the excessive abundance of opportunists following the anoxia event in 1988, while the analysis of SPI data was able to detect the important physical disturbance of the seabed due to assumed intensified fishing activities during 1995-96. Although no direct numbers are available for fishing effort at this station it can be considered to intensify because of the increasing number of images with clear signs of physical disturbance (chaotic fabric, mud clasts and removed surface layer) of the upper centimeters (Fig. 1), which is in accordance with the national fishery statistics data, in which the year 1992 was found to be the historically lowest in cod stocks in the Western Baltic (Hammer \& Hubold 1998). The landings increased considerably in the following years, which, at least in part, should be attributed to increased fishing effort.

Nilsson \& Rosenberg (1997) have developed a benthic habitat quality index (BHQ) where selected benthic attributes are summarized in a single value ranging from 0 to 15 , expanding a previously proposed organism-sediment index (Rhoads \& Germano 1986). The BHQ and the organism-sediment index are useful descriptors of the ecological 'quality' of a soft-sediment habitat since they are the sum of values of attributes which are positively related to the life requirements of macrofauna. However, these indices are inevitably subjective since the weight applied to each attribute determines its contribution to the total index value. In the methodology adopted within the present paper, 
each of the different characters measured through SPI maintains its 'individuality' whereas each sampling event (station with set of replicates) is perceived as a multiple variable allowing for intercomparisons among stations through multivariate techniques in the same way as with macrofaunal data. In this approach an infinite number of SPI attributes could be included, allowing for a further and more focused exploitation of the SPI method. It is also worth noting that in this approach there is no assumption regarding the importance of each attribute.

The general methodological approach presented in this paper could be useful for further investigating the benefit of coupling both macrofaunal and SPI data in investigating long-term changes in the marine environment.

Acknowledgements. The authors thank Hartmut Schoman and Renate Schüt for their help in producing and evaluating the data. Wolfgang Hukriede and Bodo Meusel made the data electronically available for this analysis. Thanks are also due to John Gray, Richard Warwick and 2 anonymous reviewers for helpful comments on the manuscript. This study was financially supported by grants from the German DRL International Bureau of BMBF and the General Secretariat for Research and Technology of Greece in the framework of the German-Greek cooperation agreement in Science and Technology (GRI-079-97).

\section{LITERATURE CITED}

Andersin AB, Cederwall $H$, Gosselck F. Jensen J, Josefsson A, Lagzdins G, Rumohr H, Warzocha J (1990) Second periodic assessment of the state of the marine environment of the Baltic Sea, 1984-1988; background document. Baltic Sea Environ Proc 35:211-275

Arntz WE (1981) Zonation and dynamics of macrobenthos biomass in an area stressed by oxygen deficiency. In: Barrett GW, Rosenberg R (eds) Stress effects on natural ecosystems. Wiley \& Sons Ltd, Chichester, p 215-225

Arntz WE, Rumohr H (1986) Fluctuations of benthic macrofauna during succession and in an established community. Meeresforsch 31:97-114

Bray JR, Curtis JT (1957) An ordination of the upland forest communities of southern Wisconsin. Ecol Monogr 27: $325-349$

Clarke KR, Warwick RM (1994) Changes in marine communities: an approach to statistical analysis and interpretation. Plymouth Marine Laboratory, Plymouth

Ferraro SP, Cole FA (1990) Taxonomic level and sample size sufficient for assessing pollution impacts on the Southern California Bight macrobenthos. Mar Ecol Prog Ser 67: $251-262$

Field JG, Clarke KR, Warwick RM (1982) A practical strategy for analysing multispecies distribution patterns. Mar Ecol Prog Ser 8:37-52

Grassle JF, Lasserre P, McIntyre AD, Ray GC (1991) Marine biodiversity and ecosystem function. Biol Int Spec Issue 23:1-19

Hammer C, Hubold G (1998) State and development of selected fishery resources. Annual report on German fisheries 1998. BML, Bonn, p 181-191
Nilsson HC, Rosenberg R (1997) Benthic habitat quality assessment of an oxygen stressed fjord by surface and sediment profile images. J Mar Syst 11:249-264

O'Connor BDS, Costelloe J, Keegan BF, Rhoads DC (1989) The use of REMOTS technology in monitonng coastal enrichment resulting from mariculture. Mar Pollut Bull 20: $384-390$

Olsgard $F$ (1993) Do toxic algal blooms affect subtidal softbottom communities? Mar Ecol Prog Ser 102:269-286

Olsgard F, Somerfield PJ, Carr MR (1997) Relationships between taxonomic resolution and data transformations in analyses of a macrobenthic community along an established pollution gradient. Mar Ecol Prog Ser 149: $173-181$

Olsgard F, Somerfield PJ, Carr MR (1998) Relationships between taxonomic resolution, macrobenthic community patterns and disturbance. Mar Ecol Prog Ser 172:25-36

Pearson TH, Rosenberg R (1978) Macrobenthic succession in relation to organic enrichment and pollution of the marine environment. Oceanogr Mar Biol Annu Rev 16:229-311

Rhoads DC, Boyer LF (1982) The effects of marine benthos on physical properties of sediments. A successional perspective. In: McCall PL, Tevesz MJS (eds) Animal-sediment relations. Plenum, New York, p 3-52

Rhoads DC, Germano JD (1982) Characterization of organism-sediment relations using sediment profile imaging: an efficient method of Remote Ecological Monitoring of the Seafloor (REMOTS ${ }^{\text {TM }}$ System). Mar Ecol Prog Ser 8: $115-128$

Rhoads DC, Germano JD (1986) Interpreting long-term changes in benthic community structure: a new protocol. Hydrobiologia 142:291-308

Rhoads DC, Young DK (1970) The influence of deposit feeding organisms on sediment stability and community trophic structure. J Mar Res 28:150-178

Rhoads DC, Young DK (1971) Animal-sediment relations in Cape Cod Bay, Massachusetts. II. Reworking by Molpadia oolitica (Holothuroidea). Mar Biol 11:255-261

Rosenberg R, Diaz RJ (1993) Sulfur bacteria (Beggiatoa spp.) mats indicate hypoxic conditions in the inner Stockholm archipelago. Ambio 22:32-36

Rumohr H (1990) Soft bottom macrofauna: collection and treatment of samples. ICES, Techniques in Marine Environmental Sciences, No. 8. ICES, Copenhagen

Rumohr H (1993) Erfahrungen und Ergebnisse aus 7 Jahren Benthosmonitoring in der südlichen Ostsee. In: Duinker JC (ed) Das Biologische Monitoring der Ostsee im Institut für Meereskunde Kiel 1985-1992. Ber Inst Meereskunde 240, p 90-109

Rumohr H (1995) Monitoring the marine environment with imaging methods. Sci Mar 59:129-138

Rumohr H (1996) Biologische Sukzessionen nach physikalischen Störungen am Boden der Ostsee. Baggern und Verklappen im Küstenbereich. BfG-Mitteilungen No. 11, Koblenz, p 73-76

Rumohr $H_{1}$ Schomann $H$ (1992) REMOTS sediment profiles around an exploratory drilling rig in the southern North Sea. Mar Ecol Prog Ser 91:303-311

Rumohr H, Bonsdorff E, Pearson TH (1996) Zoobenthic succession in Baltic sedimentary habitats. Arch Fish Mar Res 44:179-214

Sokal RR, Rohlf FJ (1978) Introduction to biostatistics. Freeman, New York

Somerfield PJ, Clarke KR (1995) Taxonomic levels in marine community studies, revisited. Mar Ecol Prog Ser 127: $113-119$

Warwick RM (1986) A new method for detecting pollution 
effects on marine macrobenthic communities. Mar Biol 92 $557-562$

Warwick RM (1988a) The level of taxonomic discrimination required to detect pollution effects on marine benthic communities. Mar Pollut Bull 19:259-268

Warwick RM (1988b) Analysis of community attributes of the

Editorial responsibility: Otto Kinne (Editor),

Oldendorf/Luhe, Germany macrobenthos of Frierfjord/Langesundfjord at taxonomic levels higher than species. Mar Ecol Prog Ser 46:167-170

Weigelt $M$ (1991) Short- and long term changes in the benthic community of the deeper parts of Kiel Bay (Western Baltic) due to oxygen depletion and eutrophication. Meeresforsch Rep Mar Res 33:197-224

Submitted: February 8, 1999; Accepted: July 13, 1999 Proofs received from author(s): November 17, 1999 